\title{
Mastitis incidence and bacterial causative agents isolated from lactating she-camel (Camelus dromedaries).
}

\author{
Alamin,M.A ${ }^{1,2}$;Alqurashi,A.M ${ }^{2}$; Elsheikh,A.S. and Yasin, T. E \\ Department of Preventive Medicine and Veterinary Public Health, Faculty of Veterinary Medicine, \\ University of Khartoum \\ ${ }^{2}$ Department of Applied Medical Sciences, Community college, Najran University, Saudi Arabia
}

\begin{abstract}
This study was carried out to determine the incidence of mastitis in lactating she-camel in North Kordofan State, Sudan. Furthermore, the causative bacterial agents were identified. Sixty lactating she-camels were examined clinically for mastitis. Thereafter milk samples ( $n=216$ samples) were collected from each quarter of the udders of the she-camels. The samples were subjected to white side test (WST), somatic cell count test (SCC) and bacteriological examination. The results of the clinical examination revealed that the incidence of mastitis was $25 \%$ ( $n=15$ she-camels) while upon the WST and SCC were $15 \%$ ( $n=9$ she-camels) and $13.33 \%$ $(n=8$ she-camels), respectively. However, the incidence of mastitis $(41.66 \%)$ was significantly high $(p<0.001)$ when the milk samples were bacteriological examined $(n=25$ she-camel).The bacterial examination revealed that the predominant cause is Staphylococcus spp. (80.30\%) followed by Bacillus spp. (9.09\%), Pasteurella spp. (6.06\%), Corynebacteria spp. (3.03\%), and Streptococcus spp. (1.52). It is concluded that the mastitis prevails in lactating she-camels in North Kordofan State and the most predominant cause of mastitis are Staphylococcus species. Mastitis emerges as a serious hazard and problem that affect a resource essential for many nomadic tribes that lives in the desert and semi desert areas. A national program to diagnose and compact this disease should be launched.
\end{abstract}

Keywords: she-camel; mastitis; WST; SCC

\section{Introduction}

The camels (Camelus dromedarius) are widely spread in all Sudan sates (Mohamed, 1992). They play a substantial economic role in the live hood of many rural families (Yagoub, 2003). Many camel farms have been developed recently in many cities of Sudan to augment the camel production particularly milk for its high nutritive value and its curative activity against many diseases (Hesham et al., 2012). Consequently, many lactating she-camels are been selected and transported from their production areas to be bred in urban areas. This will increase the economic value of she-camels and improve the income of the camel breeders in rural areas.

The importance of the she-camel udder healthiness in determination of its value couldn't be ignored. Although, the camels live in the desert and semi desert area, a very harsh environment with sparse water source and green pasture, they provide an ample amount of milk. This milk is an important source of protein (Yagoub, 2003) for nomadic tribes and the ignored rural citizens. Also it is a good source of vitamin $\mathrm{C}$ in these areas where the traditional sources of vitamin C are rare (Schwartz and Diole, 1992; Wilson, 1998).Unfortunately, many reports revealed that lactating she-camel catch mastitis easily (Abdurhman et al., 1995, Obied et al.,1996, Abdel Gadir et al., 2006). The camel mastitis causes the she-camel to suffer, reduces the milk production consequently the she-camel price. Furthermore, the milk properties are changed and it s processing and preservation are impaired (Fthenakis and Jones, 1990, Tibary and Anouassi, 2000). In the Sudan few reports showed that many she-camels suffer from mastitis at variable degree (Nuha, 2001, Amel, 2003, Elayis, 2004). Also, little is known about the causative agents of mastitis in the Sudan (Obied et al., 1996, Suheir, 2004).There are two types of mastitis, clinical and sub-clinical mastitis. Sub-clinical mastitis in camels refers to the existence of inflammation in the absence of gross signs and can be detected by indirect tests. Such as, somatic cells count (SCC) which is used as diagnostic tool to detect sub-clinical mastitis in camels (Quinn. et al., 1994). Also, white side test (WST) is a very cheap and easy field test for the diagnosis of mastitis (Saad and Thabet, 1993).

Mastitis is a herd problem that couldn't be ignored. Therefore it's incidence and causative agents(s) should exploited. Thus, the objective of this study was to determine incidence of mastitis in lactating she-camel in North Kordofan state. Furthermore, the study aimed to isolate and identify the causative agent(s).

\section{1- Study Area.}

\section{Materials And Methods}

This study was carried out in North Kordofan State, which lies between latitudes $9-16.8^{\circ} \mathrm{N}$ and $27-32^{\circ}$ E. 
The area is sandy with ridges. Some valleys, seasonal water pools and clay plains are scattered in the State. Also, the area being desert and semi-desert, the camel's owners live a nomadic life, migrating from place to another searching for water and grass. The vegetation of the area is composed of trees and grasses of different densities. The annual rainfall reaches averages of $300 \mathrm{~mm}$ in the North of the state to $600 \mathrm{~mm}$ in the South. Temperature ranges between $10^{\circ} \mathrm{C}$ in the cool dry season (from November, February) to $45^{\circ} \mathrm{C}$ in the hot dry season (from March, June), while in the hot wet rainy season (from July, October), the temperature varies according to humidity from $25^{\circ}-45^{\circ} \mathrm{C}$.

\section{2- Clinical examination}

Before the collection of milk samples, the lactating she-camelswere restrained.They were then examined by palpation of the udder quarters. The she-camel is considered mastitic when the udder is swollen, hard,have some lesions, painful when pressed or the stripped milk color and consistency are changed (Quinn et al., 1994).

\section{3- Samples Collection}

A total of 216 milk samples were collected from 60 lactating she-camels. The milk was collected under strict aseptic condition. The first few squirts of milk were discarded and about 5-10 $\mathrm{ml}$ of milk were collected in a sterile disposable plastic tube. The quarter milk samples were kept in an ice-box and transported as soon as possible to Elobied Veterinary Research Laboratory and were cultured for bacteriological analysis.

\section{4- White side test}

The white side test was performed according to Saad and Thabet, (1993) on glass slide onto black ground, $4 \% \mathrm{NaOH}$ solution was mixed with the milk of each quarter in a ratio of 1:5.The she-camel is considered mastitic when it's milk become viscid and thick.

\section{5- Somatic cell count}

The somatic cell count (S.C.C.) was doneaccording to standardized cell count methods (Packard et al., 1992). An amount of $0.01 \mathrm{ml}$ milk sample was spread over an area of $1 \mathrm{~cm}^{2}$ on a glass slide. The smear was dried and heated slowly to prevent cracking and peeling. The smears were stained with Newman's stain for two minutes, washed gently in water, and then the leukocytes were counted according to the following equation:

Leukocyte count $=\frac{\text { Number of leucocytes counted } \times \mathrm{MF}}{\text { Number of fields counted }}$

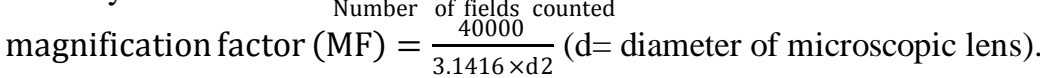

Somatic cell counts (SCC) of $2.5 \times 10^{5} \mathrm{cell} \mathrm{ml}^{-1}$ were used as the cut-off point to classify the milk samples as positive in this assay (Radostits et al., 2000).Therefore, readings above 250,000 cells $/ \mathrm{ml}$ were considered positive.

\section{6- Bacteriologicalprocedures}

Frozen milk sample were thawed at room temperature and a bacteriological loop full of milk was streaked on 5\% blood agar and Mac Conkey agar (Barrow and Feithar, 1995). The plates were incubated aerobically at $37^{\circ} \mathrm{C}$ for $18-24$ hours. Pure culture was obtained by sub-culturing part of typical and well isolated colony on a corresponding medium. This method was repeated at least twice. The resulting growth was checked for purity by examining smears stained by gram's stain. Pure isolates were identified by using standard biochemical tests (Cowan and Steel, 1985).

\section{7- Statistical analysis}

Data were presented in percentile form. The incidence of mastitis obtained by the different tests was compared with Chi- $x^{2}$. Probabilities of $\mathrm{p}<0.05$ were considered significant.

\section{Results}

As shown in fig. 1 the incidence of mastitis in lactating she-camels was significantly $(p<0.001)$ high when the milk samples were subjected to bacteriological examination. Upon clinical examination the incidence of mastitis was $25 \%(\mathrm{n}=15$ she-camels) while with the WST, SCC and bacteriological examination the incidences were15\% ( $\mathrm{n}=9$ she-camels), 13.33\% ( $\mathrm{n}=8$ she-camels), and $41.66 \%$ ( $\mathrm{n}=25$ she-camels), respectively. The percentage of she-camels that suffered from subclinical mastitis was $16.66 \%$. The main isolates were Staphylococci spp. $80.30 \%$, Bacillus spp. 9.09\%, Pasteurellas haemolytica $6.06 \%$, Corynebacterium spp. 3.03\% and Streptococcus dysgalactiae 1.52\% (Table 1). All these bacterial spp. were isolated from the subclinical cases except the Bacillus cereus of which 2 isolates were from clinical cases. 


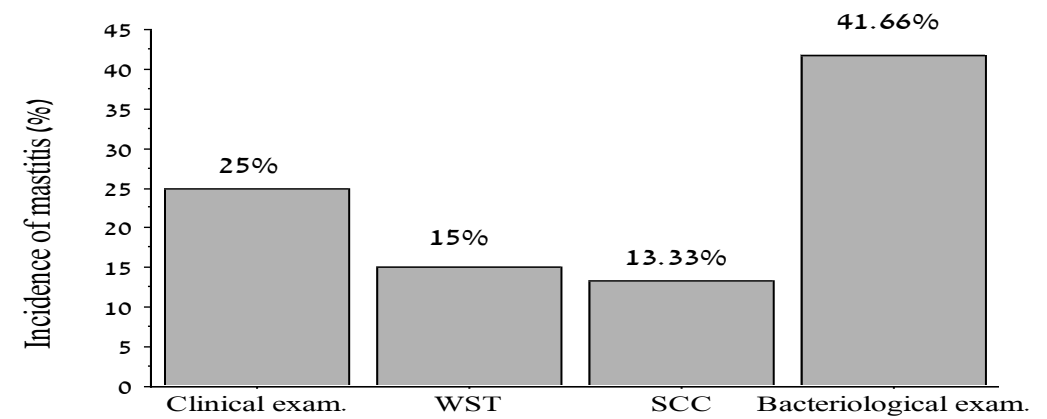

Fig. (1): Incidence of mastitis in lactating she-camel. Bacteriological examination result was significantly $(\mathrm{p}<0.001)$ higher than WST (White side test) and SCC (somatic cell count test) results.

Table (1): Different bacterial species isolated from lactating she-camels suffering from subclinical mastitis.

\begin{tabular}{lcc}
\multicolumn{1}{c}{ Species } & No. of isolates & Total $\mathrm{n}(\%)$ \\
\hline Staphylococcus aureus & 15 & $15(22.75)$ \\
S. hyicus & 2 & $2(3.03)$ \\
S. intermedius & 5 & $5(7.56)$ \\
S. epidermidis & 8 & $8(12.12)$ \\
S. delphini & 2 & $2(3.03)$ \\
S. simulans & 4 & $4(6.06)$ \\
S. kloosii & 3 & $3(4.55)$ \\
S. carnosus & 1 & $1(1.52)$ \\
S. chromogenes & 1 & $1(1.52)$ \\
S. lentus & 3 & $3(4.55)$ \\
S. lugdunensis & 2 & $2(3.03)$ \\
S. sacchrolyticus & 1 & $1(1.52)$ \\
S. saprophyticus & 2 & $2(3.03)$ \\
S. haemolyticus & 4 & $4(6.06)$ \\
Strep.dysgalactiae & 1 & $1(1.52)$ \\
Corynebacteriumbovis & 2 & $2(3.03)$ \\
Bacillus cereus & 6 & $6(9.09)$ \\
Pasteurellahaemolytica & 4 & $4(6.06)$ \\
\hline
\end{tabular}

\section{Discussion}

The results of the present study showed that mastitis prevails in lactating she-camels in North Kordofan State and the most predominant cause of mastitis is Staphylococcus species.

Many studies conducted on mastitis in she-camel in the Sudan (Salwa, 1995; Amel, 2003; Suheir, 2004) concentrated mainly on the isolation and identification of the causative agent(s). In the present study the incidence of camel mastitis was evaluated by clinical examination; WST; SCC test and bacteriological examination. High percent of the she-camels tested suffered subclinical mastitis which was discovered only upon bacteriological examination. The predominant cause isolated was Staphylococcus spp. This result agrees with that of Suheir (2004), Abdurahman et al., (1995) and Amel (2003). Contrary, (Saleh and Faye, 2011) reported that the most predominant cause is Streptococci spp. Staphylococcus aureus and coagulase-negative Staphylococci were the most bacteria isolated from she-camels suffering from sub-clinical mastitis. They represented $80.3 \%$ of the total isolates which is higher than that reported by Amel (2003) and Suheir (2004).This type of mastitis might spread between she-camels due to the bad milking habits and/or the use of local antisuckling devices. Many of the she-camels examined suffered wounds on teats caused by the piece of wood and cloth used in the antisuckling devices. Through these wounds the Staphylococcus spp, which is usually found in wounds, may invaded the mammary gland tissues.

The incidence of Corynebacterium bovis in the milk of mastitic she-camel resembles the findings of Abdel Gadir (2001), Almaw and Molla, (2000), Salwa (1995), Amel (2003) and Abdurahman et al., (1995). However, the finding it differs from that of Suheir (2004) who reported high percent of Corynebacterium bovis infection.

Our results also revealed a low percent of Streptococcus dysagalactiae. These findings were lower than those reported by Suheir (2004) and Amel (2003) who reported a higher percent (17.39\% and 13.6\%, respectively).

Although Bacillus cereus was isolated in this study its incidence was very low. This finding contrasts those reported by Salwa (1995) who stated that the main causative agent of all types of she-camel mastitis is 
Bacillus cereus. Also Ramadan et al., (1987) and Hafiz et al., (1987) reported that Bacillus cereus is the main causative agent of all types of she-camel mastitis.

In this study the gram-negative bacterium (Pasteurella haemolytica) was isolated from cases of clinical and sub-clinical mastitis. The results were in agreement with those of Bekele and Molla (2001) who isolated Pasteurella haemolytica from sub-clinical mastitis cases. Nevertheless, Radostits et al., (2000) considered this bacterium as an uncommon pathogen that cause sporadic and sever mastitis.

\section{Conclusion}

It is concluded that mastitis prevails in lactating she-camels in North Kordofan State and the most predominant causes of mastitis are Staphylococcus species. Mastitis emerges as a serious hazard and problem that affect a resource essential for many nomadic tribes that lives in the desert and semi desert areas. A national program to diagnose and compact this disease should be launched.

\section{References}

[1] Abdel Gadir, A. E., (2001): Cross-sectional study of mastitis in camels (Camelusdromedarius) in selected sites of Ethiopia. Thesis MSC, Freie Universität Berlin and Addis Ababa University.

[2] Abdel Gadir, A. E., Hildebrandt, G., Kleer, J. N., Molla, B., Kyule, M., Baumann, M. P., (2006): Comparison of California Mastitis Test (CMT), Somatic Cell Count (SCC) and bacteriological examinations for detection of Camel (Camelus dromedarius) mastitis in Ethiopia. Berl. Munch. Tierarztl. Wochenschr. 119:45-49.

[3] Abdurahman, O. S. H., Aga, H., Abbas, N.,Astom, G., (1995): Relation between udder infection and somatic cells in Camelus dromedarius milk. Acta Vet. Scand., 63(4): 424-431.

[4] Amel, M. A., (2003): Bacteria and fungi isolated from she-camel mastitis in the Red Sea Area of the Sudan. Thesis MSc, University of Khartoum, Sudan.

[5] Barrow, G. I., Feltham, R. K. A., (1993): Crown and steel's manual for identification of medical bacteria. $3^{\text {rd }}$ ed. Cambridge University Press.

[6] Bekele, T.,Mulla, B., (2001): Mastitis in lactating camels (Camelus dromedarius) in Afar region, north-east Ethiopia. Berlin Münch. Tierärztl. Wochenschr, 114(5-6): 169-172.

[7] Cowan, S. J., Steel, K. J., (1985) Manual for identification of Medical bacteria $2^{\text {nd }}$ ed. London, Cambridge University Press.

[8] Elayis, A. A., (2004): Studies on staphylococci associated with bovine mastitis in KhartoumState. Sudan. Thesis MSc, University of Khartoum, Sudan.

[9] Fthenakis, G. C., Jones, J. E. T., (1990): Subclinical mastitis and milk loss. Brit. Vet. J. 146:43.

[10] Hafez, A. M.,Fazig, S. A., El Amrousi, S.,Ramadan, R. O., (1987): Studies on mastitis on farm animals in Al Hassa: I-Analytical studies. Assoc. Vet. Med. J., 19(37): 140-145.

[11] Hesham, M. K., Mohamed, A. M. E., Abdulqader A. A., (2012): Camel Milk

[12] Modulates the Expression of Aryl Hydrocarbon Receptor-Regulated Genes, Cyp1a1, Nqo1, and Gsta1, in Murine hepatomaHepa 1c1c7 Cells. J. Biomed. Biotech. (2012), Article ID 782642, 10 doi:10.1155/2012/782642

[13] Mohammed, B. A. A.,(1992): Aerobic Bacteria of lymph nodes of the dromedary camel. Thesis MSc, University of Khartoum, Sudan.

[14] Nuha, E. I., (2001): Staphylococcal species in normal and mastitic milk of some domestic farm animals. Thesis MSc, University of Khartoum, Sudan.

[15] Obied, A. I. M., Bagadi, H. O.,Mukhtar, M. M., (1996): Mastitis in Camelus dromedarius and the somatic cell count of camel's milk. Res. Vet. Sci. 61(1): 55-58.

[16] Packard, V. S.,Tatini, J. S.,Fugua, R., Heady, J.,Gilm`an, C., (1992): Direct microscopic methods for bacteria or somatic cells. In: Marchal, R. (ed), standardized methods of the examination of dairy products, $16^{\text {th }}$ ed. American Public Health Association, NW, Washington, D. C., pp 309-324.

[17] Quinn, P. J., Carter, M. E., Markey, B., Carter, G. R., (1994): Clinical Veterinary Microbiology. $1^{\text {st }}$ ed. Wolfe Publishing, London, UK.

[18] Radostits, O. M., Gay, C. C., Blood, D. C., Hinchcliff, K. W., (2000): Veterinary Medicine. $9^{\text {th }}$ ed. Harcourt Publisher Ltd, London, UK, pp 563-700.

[19] Ramadan, R.O., El Hassan, A. M., A. M., Abdin-Bey, R., Al Gasnawi, Y. A., Abdalla, E. M., Fayed, A. A., (1987) Chronic obstructive mastitis in the camel a clinicopathological study. Cornell Vet.77 (2): 132-150.

[20] Saad N. M., Thabet, A. R., (1993): Bacteriological quality of camel's milk with special reference to mastitis. Assiut Vet. Med. J. 28(56): 194-199.

[21] Saleh, S. K., Faye, B., (2011): Detection of subclinical mastitis in dromedary camels (Camelus dromedaries) using somatic cell counts, california mastitis test and udder pathogen.Emir. J. Food Agric. 2011. 23 (1): 48-58.

[22] Salwa, M. S., (1995): Studies on camel mastitis, Atiology, clinical picture and milk composition. Thesis MSc, University of Khartoum, Sudan.

[23] Schwartz, H. J.,Dioli, M. (eds) (1992): Introduction the camel (Camelus dromedarous) in eastern Africa. In: The one humped camel in eastern Africa. A pictorial guide to diseases healthcare and management. VerlagJösef Margraf, Weiker sheim, F. R. Germany, pp $1-9$.

[24] Suheir, I. A., (2004): Some bacterial species, mycoplasma and fungal isolates associated with camel mastitis. ThesisMSc, University of Khartoum, Sudan.

[25] Thrusfield, M. (eds) (1995): Veterinary Epidemiology. $2^{\text {nd }}$ ed. Blackwell Science Ltd. UK.

[26] Tibary, A., Anouassi, A., (2000): Lactation and udder disease. In: Recent Advances in Camelid Reproduction. International veterinary Information Service. Skidmore, L. and Adams, G.P. (eds.) (www.ivis.org.)

[27] Wilson, R. T., (1998): The camels. The Tropical Agricultural Series, London and Basingstoke, UK. McMillan Education Ltd., published in co-operation with the CTA, Wageningen, the Netherlands.

[28] Yegoub, I. A., (2003): Studies on epidemiology, characterization and pathogenicity of Eimeria species in Sudanese camels. ThesisPhD, University of Khaartoum, Sudan. 